\title{
A Study on the Influence of Entrepreneurial Competence Characteristics on the Sustainability of Entrepreneurs
}

\section{-Focused on the Mediating Effects of Entrepreneurial Mentoring}

\author{
Sung-Je Lee ${ }^{1} \&$ Inchae Park $^{2}$ \\ ${ }^{1}$ Department of Smart Convergence Consulting, Hansung University, Seoul, South Korea \\ ${ }^{2}$ Division of Smart Management Engineering, Hansung University, Seoul, South Korea \\ Correspondence: Inchae Park, Assistant Professor, Division of Smart Management Engineering, Hansung University, \\ 116 Samseongyoro-16gil, Seongbuk-gu, Seoul, 02876, South Korea. Tel: 82-10-5485-4559. E-mail: \\ ipark@ hansung.ac.kr
}

Received: April 9, 2020

Accepted: May 9, 2020

Online Published: May 23, 2020

doi:10.5430/rwe.v11n2p12

URL: https://doi.org/10.5430/rwe.v11n2p12

\begin{abstract}
Background/Objectives: Many studies have shown that the ability of a startup to have a significant impact on the sustainability of the startup, but no studies have been conducted on whether the ability of the startup to influence startup sustainability using startup mentoring. Therefore, this study investigated whether the founder's competency characteristics influence sustainability through the medium of start-up mentoring.

Methods/Statistical analysis: The study subjects were early founders, and the survey was conducted as a survey method. The survey items consisted of 62 questions including 12 demographics. The Likert 5-point scale was used for the measurement. For the empirical analysis, frequency analysis, descriptive statistical analysis, exploratory factor analysis, reliability analysis, correlation analysis, regression analysis, and mediation effect analysis were performed using SPSS Ver. 22 statistical package.

Findings: The results of the study confirm that entrepreneurial competence characteristics are partially mediated by the characteristics of the technical capability and the strategic thinking capability on the impact of sustainability, and through the research, the organizational capability of entrepreneurial competence characteristics are completely mediated on the impact on the sustainability.

Improvements/Applications: In order to secure the sustainability of start-ups, mentors should conduct mentoring by understanding the entrepreneurial competence characteristics. Mentoring that does not fit the entrepreneurial competence characteristics only forces the founder to regenerate time and effort. Mentors should participate in entrepreneurial mentoring with a sense of mission for the national economy and job creation, and government support policies should be tailored to the characteristics of entrepreneurs.
\end{abstract}

Keywords: entrepreneurial competence characteristics, technical capability, strategic thinking capability, organizational capability, entrepreneurial mentoring, sustainability

\section{Introduction}

According to Korean Statistical Office data, 6,250,000 companies are operating in 2018, an increase of 3.3\% year-on-year, with 920,000 companies created and 698,000 companies closed in 2018. Among the companies in 2017, the start-up survival rate for new startups was $65.0 \%$ in 2016, and the 5-year survival rate for startups was $29.2 \%$ in 2012 . The survival rate of startups decreases year by year, with a five-year survival rate of $29.2 \%$, closing $70.8 \%$ of startups five years after startup. In terms of number of employees, the number of active companies in 2018 is $20,414,000$, the number of new startups is $1,366,000$, and in 2017, 941,000 are closed. Every year, companies start their own businesses, but more and more companies are disappearing. The significant data for corporate survival statistics are the ratio of active companies to extinction companies by age group. The percentage of companies that are extinct compared to the number of active businesses was $20.3 \%$ for under $30 \mathrm{~s}, 15.25 \%$ for $30 \mathrm{~s}, 11.33 \%$ for $40 \mathrm{~s}$, $9.51 \%$ for $50 \mathrm{~s}$, and $9.65 \%$ for $60 \mathrm{~s}$. By age group, it is seen that under $20 \mathrm{~s}$ is the highest, and as the age group rises, 
the ratio of extinction companies to active companies decreases. It is hypothesized that this is because experiences and economy grow with age, and it is easy to acquire information through network. This study was conducted to verify this. It was judged that entrepreneurship education and mentoring could play a significant role as a way to complement the lack of experience, economy and network for young founders. The founder's overall knowledge, ability, and lack of experience in entrepreneurship are the third factors in the start-up disorder, followed by a lack of start-up funds and fear of failure. Although the entrepreneurship statistics show that the rate of entrepreneurship increases year by year, the 5-year survival rate drops to $29.2 \%$. In order to increase the survival rate of the start-up companies and to ensure sustainability, the research on whether the start-up companies could have a significant influence on mentoring to compensate for the lack of experience and the economy was started.

\section{Materials and Methods}

\subsection{Entrepreneur Competency Characteristics}

A successful business is created by someone with a strong entrepreneurial ability as an entity that can move opportunities into action, whether or not they are right. Competencies are characteristic separating superior performance, average, and poor performance, and are inherent characteristics inherent in specific individuals, such as motivation, characteristics, magnetic images, skills, social roles, and knowledge systems that are crucially relevant to effective or outstanding performance (Boyatzis, 1982). Also, Competence is an internal characteristic of an individual who causes efficient and good performance based on criteria in a specific job or situation (Spencer and Spencer, 2008). In the field of corporate management, such as technology start-ups and venture companies, entrepreneurship capabilities are generally conceptualized with knowledge, skills, and skills that can produce effective or outstanding management performance in a particular job (Hamel and Prahalad, 1990). Competencies are the basic characteristics of individuals with effective and good management outcomes and causal relationships based on job criteria (McClelland, 1987). Based on various studies, the entrepreneurial competence characteristics include technical capability, strategic thinking capability, and organizational capability (Kim et al., 2014; Hyuk and Park, 2019).

\subsubsection{Technical Capability}

Technical competencies are of expertise in the field (Chandler and Hanks, 1994). Technical-functional competency is a concept that represents the entrepreneur's expertise in a particular field of expertise. In other words, the ability of an entrepreneur to use specialized tools, procedures, and skills (Pavett and Lau, 1983). Technology-based technology competencies can be defined as technical skills related to product development and production, which include the knowledge and techniques necessary for the selection, acquisition, improvement and use of technology (Barney, 1991).

\subsubsection{Strategic Thinking Capability}

A strategy defined as a corporate theory of how companies can achieve higher performance in the market (Drucker). Strategic competency is related to the entrepreneur's ability to formulate, evaluate and implement a company's strategy (Man et al., 2002). The strategy is the most effective and efficient way to achieve a long-term sustainable competitive advantage, and from a corporate perspective, it is to understand the trends and competitive situations of the industry in the market and to use its strengths and weaknesses to develop management activities most effectively and efficiently (Kim and Baek, 2019).

\subsubsection{Organizational Capability}

Organizing competency is the ability to organize and integrate technical, human, material, and financial resources inside and outside various companies into tasks (Lee and Kim, 2018). Networks are essential to the discovery of opportunities and testing of ideas, freeing up resources for new organizations (Zimmer, 1986). Contributing to the mobilization of external resources from third parties is because contact implies a positive assessment of the prospects of the start-up (Stuart et al., 1999). Provided sufficient evidence that successful entrepreneurs are particularly active in networking with entrepreneurs and regulators (Dollinger, 1985). Corporate social capital can be defined as "the set of resources that a corporate player gains through player social relationships, whether tangible or fictitious" and promotes the achievement of goals (Gabbay and Leenders, 1999).

\subsection{Entrepreneurial Mentoring}

Kram is a leading researcher on the mentoring function. It is conceptualized as a research and it is considered to be the most systematic research that summarizes the function of mentoring. Looking at the above studies, the function of mentoring is divided into Career function' and Psychosocial functions. Kram states that role model features are 
embedded in psychosocial functions, while career functions are influenced by the strength, competence and position of mentors in the organization. Psychosocial functions can be influenced by the quality of the mentor and mentee's interaction and emotional exchange activities (Kram, 1983). Burke later added Kram's two-dimensional mentoring functional classification to add' role modeling functions' that provide mentors with the knowledge and skills to guide appropriate behavior (Burke, 1984).

\subsection{Sustainability}

Sustainable management has been defined as a company's efforts aimed at sustainability in the environmental, social and economic sectors and various management activities aimed at minimizing risks and improving corporate value (Goodland and Daly, 1996). Sustainability can be interpreted in different ways depending on what is pursued in which area. In particular, in the case of a company established in various fields, since the areas of interest and the purpose of pursuing are different, the method of determining the degree may be different even if there is a certain standard (Holdren et al., 1995). In this study, the items measured for sustainability were classified into economic responsibility, environmental responsibility, and social responsibility.

\subsection{Entrepreneurial Mentoring and Entrepreneur Competency Characteristics}

It was analyzed that the role model function is derived from the mentoring function of young entrepreneurs in relation to the mentoring function for start-ups and the ability to start a business has positive influence (Gibson, 2004; Moi et al., 2011). In the case of small capital start-ups, career development functions, such as individual's experience in starting businesses or working experience in related businesses, were found to have a significant relevance to start-up capabilities, and research on mentoring and organizational immersion in Korea also showed that mentoring functions have a significant effect on organizational immersion (Smith et al., 2009). As a result, the three functions of mentoring (experience development function, psychosocial function, and role model function) all have significant effects on organizational immersion.

\subsection{Entrepreneurial Mentoring and Sustainability}

Few previous studies have identified the correlation or causal relationship between entrepreneurial mentoring and sustainability of entrepreneurs. This study attempts to test the hypothesis that entrepreneurial mentoring has a significant impact on the sustainability of entrepreneurs.

\subsection{The Research Model and Hypothesis}

\subsubsection{Research Model}

Based on previous studies that have been investigated so far, the study aims to investigate the impact of entrepreneur competency characteristics on entrepreneurial mentoring and on the sustainability of entrepreneurs. To achieve the purpose of the above research, the following research model was prepared based on the concepts and theoretical basis summarized through the previous paper research.

The research model is shown below in [Figure1].

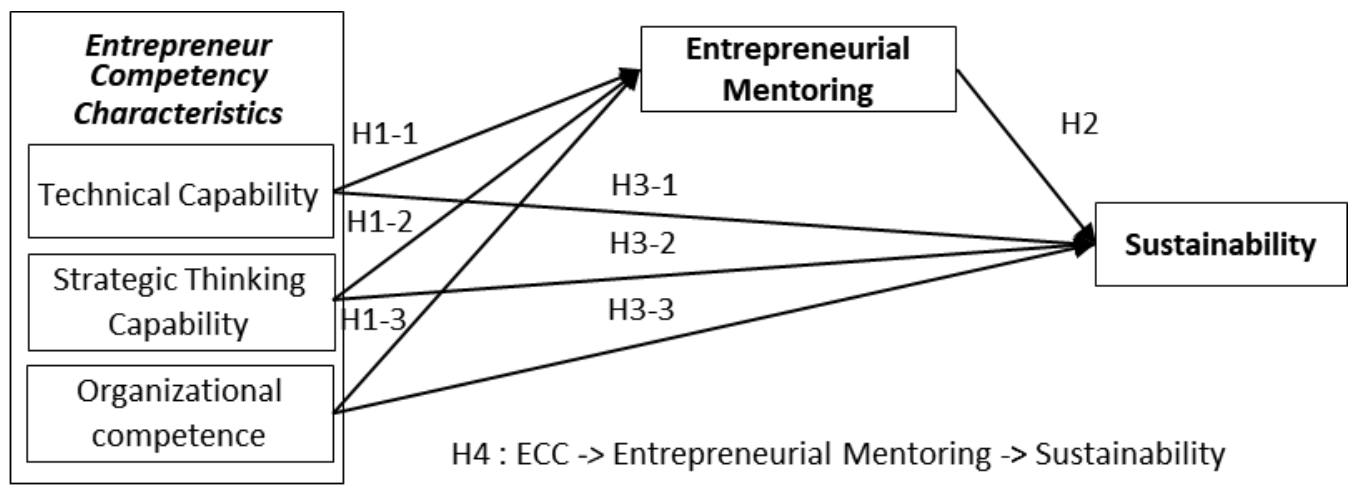

Figure 1. Research model 


\subsubsection{Research Hypothesis}

H1-1. Technical capability of entrepreneur competency characteristics will have a positive effect on Entrepreneurial mentoring.

H1-2. Strategic thinking capability of entrepreneur competency characteristics will have a positive effect on entrepreneurial mentoring.

H1-3. Organizational competence of entrepreneur competency characteristics will have a positive effect on entrepreneurial mentoring.

H2. Entrepreneurial mentoring will have a positive impact on the sustainability of entrepreneurs.

H3-1. Technical capability of entrepreneur competency characteristics will have a positive effect on sustainability of entrepreneurs.

H3-2. Strategic thinking capability of entrepreneur competency characteristics will have a positive effect on sustainability of entrepreneurs.

H3-3. Organizational competence of entrepreneur competency characteristics will have a positive effect on sustainability of entrepreneurs.

H4-1. Technical capability of entrepreneur competency characteristics will play a role in mediating the impact of entrepreneurial mentoring on sustainability.

H4-2. Strategic thinking capability of entrepreneur competency characteristics will play a role in mediating the impact of entrepreneurial mentoring on sustainability.

H4-3. Organizational competence of Entrepreneur competency characteristics will play a role in mediating the impact of entrepreneurial mentoring on sustainability.

\subsubsection{Operational Definition of Variables}

The operational definition of each variable is summarized as shown in [Table 1].

Table 1. Operational definition of variables

\begin{tabular}{|c|c|c|c|}
\hline $\begin{array}{l}\text { Evaluation } \\
\text { items }\end{array}$ & $\begin{array}{l}\text { Measurement } \\
\text { variable }\end{array}$ & Operational definition & Researcher \\
\hline \multirow{3}{*}{$\begin{array}{l}\text { Entrepreneurial } \\
\text { mentoring }\end{array}$} & $\begin{array}{l}\text { Career } \\
\text { functions }\end{array}$ & $\begin{array}{l}\text { Mentors guide, expose and present, protect, challenge, and } \\
\text { sponsor mentors for the purpose of career development }\end{array}$ & \multirow{3}{*}{$\begin{array}{l}\text { (Lim et al., } \\
\text { 2015) }\end{array}$} \\
\hline & $\begin{array}{l}\text { Psychosocial } \\
\text { functions }\end{array}$ & $\begin{array}{l}\text { Counseling, friendship, coaching, acceptance and support of } \\
\text { mentors to help mentees maintain psychological stability to } \\
\text { adapt to the organization }\end{array}$ & \\
\hline & $\begin{array}{l}\text { Role modeling } \\
\text { functions }\end{array}$ & $\begin{array}{l}\text { The ability of a mentor to present a model of the mentee as a } \\
\text { desirable senior in the organization and to help the younger or } \\
\text { junior mentee to benchmark it. }\end{array}$ & \\
\hline \multirow{4}{*}{$\begin{array}{l}\text { Entrepreneur } \\
\text { Competency } \\
\text { Characteristics }\end{array}$} & & The acquisition of expertise in the field. & \multirow{4}{*}{$\begin{array}{l}\text { (Barney, } \\
\text { 1991); } \\
\text { (Chandler } \\
\text { and Jansen, } \\
\text { 1992); } \\
\text { (Lerner and } \\
\text { Almor, } \\
\text { 2002) }\end{array}$} \\
\hline & $\begin{array}{l}\text { Technical } \\
\text { capability }\end{array}$ & $\begin{array}{l}\text { Technical skills related to product development and } \\
\text { production, including the knowledge and techniques necessary } \\
\text { for the selection, acquisition, improvement and use of } \\
\text { technology. }\end{array}$ & \\
\hline & $\begin{array}{l}\text { Strategic } \\
\text { thinking } \\
\text { capability }\end{array}$ & $\begin{array}{l}\text { Strategic Thinking capabilities are related to the ability of } \\
\text { entrepreneurs to formulate, evaluate, and implement a } \\
\text { company's strategy. }\end{array}$ & \\
\hline & $\begin{array}{l}\text { Organizational } \\
\text { competence }\end{array}$ & $\begin{array}{l}\text { Organizing competency is the ability to organize and integrate } \\
\text { human, material, financial, and technical resources within and } \\
\text { across various companies into tasks. }\end{array}$ & \\
\hline Sustainability & $\begin{array}{l}\text { Economic } \\
\text { responsibility }\end{array}$ & $\begin{array}{l}\text { Contribution to national development, creation of new } \\
\text { employment, improvement of people's living standards and } \\
\text { quality of life through continuous improvement of quality and }\end{array}$ & (Barr, 1998) \\
\hline
\end{tabular}


service, profit creation. Having a high market position,

improving brand and corporate value.

\begin{tabular}{ll}
\hline & $\begin{array}{l}\text { Support and concern for environmental protection activities, } \\
\text { continuous provision of eco-friendly products and services, } \\
\text { regular environmental protection campaigns, efficient use of } \\
\text { responsibility }\end{array}$ \\
& $\begin{array}{l}\text { resources and energy, efforts to collect and reduce waste } \\
\text { resources, compliance with environmental laws and } \\
\text { regulations }\end{array}$ \\
\hline $\begin{array}{l}\text { Social } \\
\text { responsibility }\end{array}$ & $\begin{array}{l}\text { Efforts to improve labor conditions, human rights efforts, a } \\
\text { fair society, efforts for customer health and safety, volunteer } \\
\text { activities, and social reduction of company resources }\end{array}$ \\
\hline
\end{tabular}

\section{Results and Discussion}

\subsection{Empirical Results}

This study used SPSS 22.0 statistical program and analyzed the frequency analysis, descriptive statistical analysis, and validity of measurement variables. Pearson's correlation analysis was conducted to verify the correlation between the variables set prior to reliability analysis and hypothesis testing using the $\alpha$ 's coefficient.

\subsubsection{Demographic Characteristics Analysis}

The total number of samples used in this study was 323, and the frequency analysis of the general characteristics of the distribution of samples was performed. The results showed that $84.8 \%$ (274) were male and $15.2 \%$ (49) were female. The ages were $8.4 \%$ (27) for those under 35 years old, $30.3 \%$ (98) for 45 years old, and $61.3 \%$ (198) for those over 46 years old. The highest level of educational attainment was 61.3\% (198) for graduate students and higher, followed by university graduates at 30.3\% (98) (Litimi, 2019); (Liu and Kuo, 2017).

\subsubsection{The Exploratory Factor and Reliability Analysis}

In this study, the data collected from the startup founders who had been experienced in the entrepreneurial mentoring analysis showed that the standard deviation was 3 or less, the absolute value of skewness statistics 3 or less, and the kurtosis statistical value 3 or less. A summary of the exploratory factor analysis and the reliability analysis results are shown in the following [Table 2].

Table 2. The exploratory factor and reliability analysis

\begin{tabular}{|c|c|c|c|c|c|c|c|}
\hline \multirow{2}{*}{$\begin{array}{l}\text { Measurement } \\
\text { item }\end{array}$} & \multicolumn{5}{|c|}{ Factor } & \multirow[b]{2}{*}{ Commonality } & \multirow{2}{*}{$\begin{array}{c}\text { Reliability } \\
\text { analysis }\end{array}$} \\
\hline & $\begin{array}{l}\text { Technical } \\
\text { Capability }\end{array}$ & $\begin{array}{l}\text { Strategic } \\
\text { Thinking } \\
\text { Capability }\end{array}$ & $\begin{array}{l}\text { Organizational } \\
\text { Competence }\end{array}$ & $\begin{array}{l}\text { Entrepreneurial } \\
\text { mentoring }\end{array}$ & Sustain-ability & & \\
\hline $\begin{array}{c}\text { Technical } \\
\text { Capability2 }\end{array}$ & .834 & & & & & .800 & \multirow{3}{*}{.851} \\
\hline $\begin{array}{c}\text { Technical } \\
\text { Capability4 }\end{array}$ & .802 & & & & & .778 & \\
\hline $\begin{array}{c}\text { Technical } \\
\text { Capability1 }\end{array}$ & .801 & & & & & .732 & \\
\hline $\begin{array}{c}\text { Strategic } \\
\text { Thinking } \\
\text { Capability2 }\end{array}$ & & .803 & & & & .715 & \multirow{3}{*}{.846} \\
\hline $\begin{array}{c}\text { Strategic } \\
\text { Thinking } \\
\text { Capability3 }\end{array}$ & & .792 & & & & .690 & \\
\hline $\begin{array}{l}\text { Strategic } \\
\text { Thinking }\end{array}$ & & .742 & & & & .701 & \\
\hline
\end{tabular}


Capability5

\begin{tabular}{|c|c|c|c|c|c|c|c|}
\hline $\begin{array}{c}\text { Strategic } \\
\text { Thinking } \\
\text { Capability6 }\end{array}$ & & .724 & & & & .546 & \\
\hline $\begin{array}{c}\text { Strategic } \\
\text { Thinking } \\
\text { Capabilities4 }\end{array}$ & & 692 & & & & .510 & \\
\hline $\begin{array}{c}\text { Organizational } \\
\text { Competence } 3\end{array}$ & \multicolumn{4}{|c|}{.782} & & .752 & \multirow{3}{*}{.784} \\
\hline $\begin{array}{l}\text { Organizational } \\
\text { Competence } 2\end{array}$ & \multicolumn{4}{|c|}{.778} & & .738 & \\
\hline $\begin{array}{l}\text { Organizational } \\
\text { Competence4 }\end{array}$ & \multirow{2}{*}{\multicolumn{3}{|c|}{.719}} & & & .666 & \\
\hline $\begin{array}{c}\text { Entrepreneurial } \\
\text { mentoring1 }\end{array}$ & & & & .857 & & .747 & \multirow{4}{*}{.856} \\
\hline $\begin{array}{l}\text { Entrepreneurial } \\
\text { mentoring } 3\end{array}$ & & & & .789 & & .743 & \\
\hline $\begin{array}{c}\text { Entrepreneurial } \\
\text { mentoring4 }\end{array}$ & & & & .769 & & .684 & \\
\hline $\begin{array}{c}\text { Entrepreneurial } \\
\text { mentoring2 }\end{array}$ & & & & .760 & & .661 & \\
\hline Sustainability1 & & & & & .820 & .741 & \multirow{3}{*}{.812} \\
\hline Sustainability3 & & & & & .815 & .719 & \\
\hline Sustainability2 & & & & & .809 & .713 & \\
\hline Eigen-value & 2.397 & 3.213 & 2.061 & 2.950 & 2.372 & & \\
\hline Variance $\%$ & 13.317 & 17.848 & 11.449 & 16.390 & 13.177 & & \\
\hline $\begin{array}{l}\text { Accumulated } \\
(\%)\end{array}$ & 13.317 & 31.165 & 42.614 & 59.004 & 72.181 & & \\
\hline \multicolumn{5}{|c|}{ Kaiser-Meyer-Olkin Measure of Sampling Adequacy } & & .878 & \\
\hline Bartlett's Test & phericity & $\begin{array}{l}\text { Approx. } \\
\chi^{2}\end{array}$ & 3437.240 & df & 153 & p-value & 0.000 \\
\hline
\end{tabular}

\subsubsection{Pearson's Correlation Analysis}

As a result of exploratory factor analysis in this study, correlation was obtained to find the degree of directionality and denseness among the variables of the calculated components through averaging of the measured variables with homogeneity obtained through reliability analysis and homogeneity through reliability analysis. Relationship analysis was conducted. As for the correlation between variables, technical capability showed high correlation with entrepreneurial mentoring functions $(0.651 * *)$ and Pearson correlation coefficient with organizational competence $\left(0.619^{* *}\right)$. As a result of correlation analysis of all variables, all correlations were statistically significant $(\mathrm{r} \geq .05)$.

The results of the correlation analysis are summarized as shown in [Table 3]

Table 3. Summary of correlation analysis results

\begin{tabular}{ccccccccc}
\hline Variables & $\mathrm{N}$ & Mean & $\begin{array}{c}\text { Standard } \\
\text { Deviation }\end{array}$ & $\begin{array}{c}\text { Technical } \\
\text { Capability }\end{array}$ & $\begin{array}{c}\text { Strategic } \\
\text { Thinking } \\
\text { Capability }\end{array}$ & $\begin{array}{c}\text { Organizational } \\
\text { Competence }\end{array}$ & $\begin{array}{c}\text { Entre } \\
\text {-preneurial } \\
\text { mentoring }\end{array}$ & $\begin{array}{c}\text { Sustain } \\
\text {-ability }\end{array}$ \\
\hline $\begin{array}{l}\text { Technical } \\
\text { Capability }\end{array}$ & 323 & 3.9959 & .67437 & 1 & $.458^{* * *}$ & $.619^{* *}$ & $.651^{* *}$ & $.609^{* * *}$ \\
\cline { 5 - 7 }
\end{tabular}




\begin{tabular}{ccccccccc}
\hline $\begin{array}{c}\text { Strategic } \\
\begin{array}{c}\text { Thinking } \\
\text { Capability }\end{array}\end{array}$ & 323 & 4.0217 & .59074 & $.458^{* *}$ & 1 & $.479^{* *}$ & $.450^{* *}$ & $.529^{* *}$ \\
\hline $\begin{array}{c}\text { Organizational } \\
\text { Competence }\end{array}$ & 323 & 3.8163 & .70830 & $.619^{* * *}$ & $.479^{* * *}$ & 1 & $.606^{* * *}$ & $.529^{* *}$ \\
\hline $\begin{array}{c}\text { Entre } \\
\text {-preneurial } \\
\text { mentoring }\end{array}$ & 323 & 3.9079 & .73578 & $.651^{* *}$ & $.450^{* *}$ & $.606^{* *}$ & 1 & $.569^{* *}$ \\
\hline Sustainability & 323 & 3.9236 & .74929 & $.609^{* *}$ & $.529^{* *}$ & $.529^{* *}$ & $.569^{* *}$ & 1 \\
\hline
\end{tabular}

**. The correlation is significant at the.01 level (both sides).

\subsubsection{Test of Hypothesis}

The SPSS ver.22 statistical package was analyzed to test this hypothesis.

[Table 4] shows the results of hypothesis testing of Entrepreneur Competency Characteristics and Entrepreneurial mentoring, Entrepreneur Competency Characteristics and Sustainability, Entrepreneurial mentoring and sustainability.

Table 4. Results of hypothesis test

\begin{tabular}{|c|c|c|c|c|c|c|}
\hline constructs & B & $\beta$ & $\mathrm{t}$ & $\mathrm{p}$-value & VIF & result \\
\hline (constant) & .165 & & .703 & .128 & & \\
\hline $\begin{array}{l}\text { Technical } \\
\text { Capability }\end{array}$ & .425 & .383 & 7.134 & .000 & 1.715 & accept \\
\hline $\begin{array}{c}\text { Strategic } \\
\text { Thinking } \\
\text { Capability }\end{array}$ & .352 & .277 & 5.777 & .000 & 1.373 & accept \\
\hline $\begin{array}{l}\text { Organizational } \\
\text { Competence }\end{array}$ & .169 & .160 & 2.934 & .004 & 1.759 & accept \\
\hline \multicolumn{7}{|c|}{$\begin{aligned} \mathrm{R}^{2}= & .464, \text { Adjusted } \mathrm{R}^{2}=.459, \mathrm{~F}=92.113(\mathrm{p}=<.001), \text { Durbin-Watson }=2.206 \\
& \text { Dependent variable: Sustainability }\end{aligned}$} \\
\hline (constant) & .339 & & 1.527 & .128 & & \\
\hline $\begin{array}{l}\text { Technical } \\
\text { Capability }\end{array}$ & .453 & .415 & 8.018 & .000 & 1.715 & accept \\
\hline $\begin{array}{c}\text { Strategic } \\
\text { Thinking } \\
\text { Capability }\end{array}$ & .150 & .121 & 2.601 & .010 & 1.373 & accept \\
\hline $\begin{array}{l}\text { Organizational } \\
\text { Competence }\end{array}$ & .303 & .291 & 5.552 & .000 & 1.759 & accept \\
\hline \multicolumn{7}{|c|}{$\mathrm{R}^{2}=.501$, Adjusted $\mathrm{R}^{2}=.496, \mathrm{~F}=106.744(\mathrm{p}=<.001)$, Durbin-Watson=1.997 } \\
\hline (constant) & 1.658 & & 8.923 & .000 & & \\
\hline $\begin{array}{l}\text { Entrepreneurial } \\
\text { mentoring }\end{array}$ & .580 & .569 & 12.406 & .000 & 1.845 & accept \\
\hline
\end{tabular}


The result of verifying the hypothesis is as shown in [Figure 2]

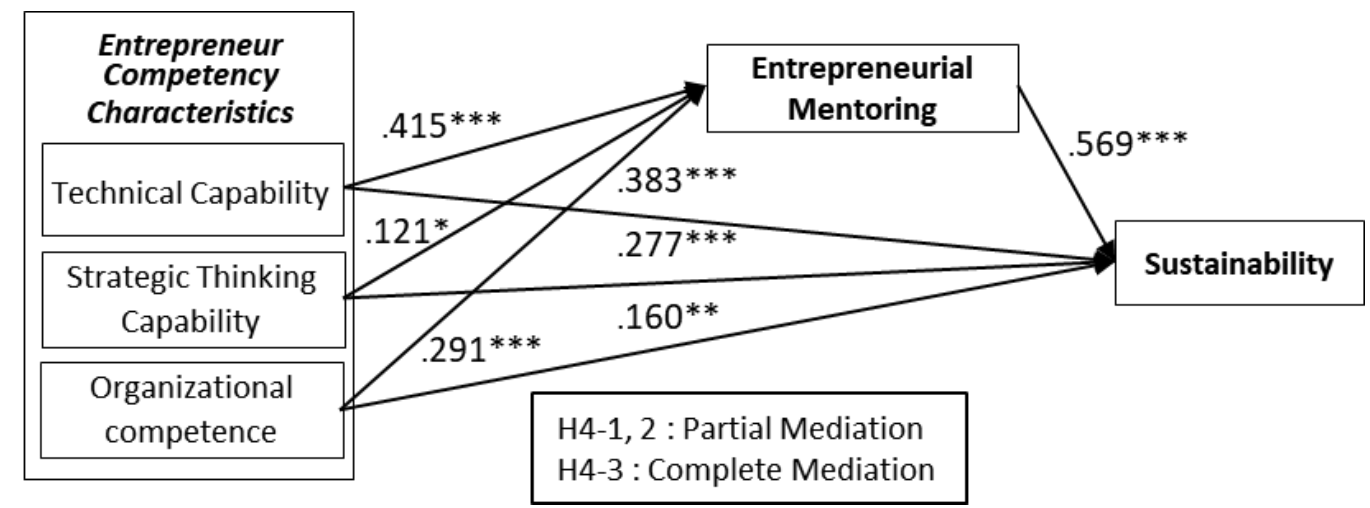

Figure 2. Hypothesis verification result

\subsubsection{Mediating Effect Analysis}

To analyze the relationship between entrepreneur competency characteristics and sustainability, the three-step approach of Baron \& Kenny was used to conduct a multiple regression analysis for the analysis of mediating effects (Baron and Kenny, 1986). In the first step, technical capability, strategic thinking capability and organizational competence had a positive effect on sustainability (Liu, 2019); (Machdar, 2019). In the second step, technical capability, strategic thinking capability and organizational ability had a positive effect on the startup mentoring. In the third step, technical capability and strategic thinking capability are partially mediated and organizational competence are fully mediated.

The results of the mediating effect analysis are summarized as shown in [Table 5].

Table 5. Mediating effect analysis of absorption

\begin{tabular}{|c|c|c|c|c|c|c|c|}
\hline \multirow{3}{*}{$\begin{array}{c}\text { Classification } \\
\begin{array}{c}\text { Dependent } \\
\text { Variable }\end{array} \\
\text { Independent } \\
\text { Variable }\end{array}$} & \multicolumn{2}{|c|}{ Step1 } & \multicolumn{2}{|c|}{ Step2 } & \multicolumn{2}{|c|}{ Step3 } & \multirow{3}{*}{$\begin{array}{c}\text { Mediated } \\
\text { effect Result }\end{array}$} \\
\hline & \multicolumn{2}{|c|}{ Sustainability } & \multicolumn{2}{|c|}{$\begin{array}{l}\text { Entrepreneurial } \\
\text { mentoring }\end{array}$} & \multicolumn{2}{|c|}{ Sustainability } & \\
\hline & B & Beta & B & Beta & B & Beta & \\
\hline (constant) & .165 & & .339 & & .097 & & \\
\hline $\begin{array}{l}\text { Technical } \\
\text { Capability }\end{array}$ & .425 & $.383^{* * *}$ & .453 & $.415^{* * *}$ & .334 & $.3011^{* * * *}$ & partial \\
\hline $\begin{array}{l}\text { Strategic } \\
\text { Thinking } \\
\text { Capability }\end{array}$ & .352 & $.277^{* * *}$ & .150 & $.121^{*}$ & .322 & $.254^{* * *}$ & partial \\
\hline $\begin{array}{c}\text { Organizational } \\
\text { Competence }\end{array}$ & .169 & $.160^{* *}$ & .303 & $.291^{* * *}$ & .108 & .102 & complete \\
\hline $\begin{array}{l}\text { Entrepreneurial } \\
\text { mentoring }\end{array}$ & & & & & .201 & $.198^{* *}$ & \\
\hline $\mathrm{R}^{2}$ & & & & & & & \\
\hline $\mathrm{F}$ & & & & & & & \\
\hline Durbin-Watson & & & & & & & \\
\hline p-value: $* \mathrm{p}<.05$ & .01 & .001 & & & & & \\
\hline
\end{tabular}




\section{Conclusion}

This study suggests the direction of the research that the entrepreneurial mentoring will mediate the relationship between the entrepreneur competency characteristics and the sustainability of the start-up company. As mentioned in the introduction, $70.8 \%$ of startups were closed within five years, and the reasons for closure are very diverse. However, the study found that the implementation of entrepreneurial mentoring, taking into account the entrepreneur competency characteristics, had a significant impact on the sustainability of startups. As a result, hiring and utilizing competent mentors that take into account the entrepreneur competency characteristics can play an important role in reducing the rate of closure and increasing the sustainability of startups. If many start-up institutions helping entrepreneurs implement entrepreneurial mentoring that takes into account entrepreneurial competency characteristics, entrepreneurs could focus on their start-up activities with more confidence. Therefore, through a detailed study of entrepreneur competency characteristics, we want to establish various entrepreneurial mentoring methodologies that can be applied to the start-up company.

\section{Acknowledgment}

This research was financially supported by Hansung University.

\section{References}

Barney, J. (1991). Firm resources and sustained competitive advantage. Journal of Management, 17(1), 99-120.

Baron, R. M., \& Kenny, D. A. (1986). The moderator-mediator variable distinction in social psychological research: Conceptual, strategic, and statistical considerations. Journal of Personality and Social Psychology, 51(6), 1173.

Barr, H. (1998). Competent to collaborate: Towards a competency-based model for interprofessional education. Journal of Interprofessional Care, 12(2), 181-7.

Boyatzis, R. E. (1982). The competent manager: A model for effective performance. John Wiley \& Sons.

Burke, R. J. (1984). Mentors in organizations. Group \& Organization Studies, 9(3), 353-72.

Chandler, G. N., \& Hanks, S. H. (1994). Market attractiveness, resource-based capabilities, venture strategies, and venture performance. Journal of Business Venturing, 9(4), 331-49.

Chandler, G. N., \& Jansen, E. (1992). The founder's self-assessed competence and venture performance. Journal of Business Venturing, 7(3), 223-36.

Dollinger, M. J. (1985). Environmental contacts and financial performance of the small firm. Journal of Small Business Management (pre-1986), 23(000001), 24.

Drucker, P. (1994). The theory of the business. Harvard Business Review.

Gabbay, S. M., \& Leenders, R. T. (1999). Corporate social capital and liability. Kluwer Academic.

Gibson, D. E. (2004). Role models in career development: New directions for theory and research. Journal of Vocational Behavior, 65(1), 134-56.

Goodland, R., \& Daly, H. (1996). Environmental sustainability: Universal and non-negotiable. Ecological Applications, 6(4), 1002-17.

Hamel, G., \& Prahalad, C. K. (1990). The core competence of the corporation. Harvard Business Review, 68(3), 79-91.

Holdren, J. P., Daily, G. C., \& Ehrlich, P. R. (1995). The meaning of sustainability: biogeophysical aspects. Defining and Measuring Sustainability: The Biogeophysical Foundations, 3-17.

Hyuk, K. H., \& Park, W. (2019). Impact of entrepreneurial business start-up motivation, entrepreneurial spirit, and entrepreneurial competence characteristics on start-up companies' sustainability: Focusing on the mediating effect of the start-up companies' business performance. Asia-Pacific Journal of Business Venturing and Entrepreneurship, 14(3), 59-71.

Kim, C. B., \& Baek, N. Y. (2019). An empirical study on the impact of entrepreneur's strategic competency and characteristics of their experiences on performance of social enterprises: Focused on the mediating effect of social-value seeking. Asia-Pacific Journal of Business Venturing and Entrepreneurship, 14(5), 43-59.

Kim, C. K., Lee, C. S., \& Kim, J. S. (2014). Analysis of factors influencing the early performance of technology-based start-ups. Korean Corporation Management Review, 57, 63-86.

Kram, K. E. (1983). Phases of the mentor relationship. Academy of Management Journal, 26(4), 608-25. 
Lee, H. Y., \& Kim, J. S. (2018). A study on the entrepreneurial competency model in early-and late-stage technology-based ventures. Asia-Pacific Journal of Business Venturing and Entrepreneurship, 13(4), 99-116.

Lerner, M., \& Almor, T. (2002). Relationships among strategic capabilities and the performance of women - owned small ventures. Journal of Small Business Management, 40(2), 109-25.

Lim, A. R., Kim, H. C., \& Kim, K. P. (2015). The effect of youth entrepreneurs' competence on entrepreneurial behavior and entrepreneurial performance. Korean Management Consulting Review, 15(3), 143-54.

Litimi, H. (2019). Regime changes in the volatility of stock markets. The Economics and Finance Letters, 6(1), 92-99.

Liu, H. H., \& Kuo, F. H. (2017). Determinants of school efficiencies from innovative teaching through digital mobile e-learning for high schools: Application of bootstrap truncated regression model. Asian Journal of Economic Modelling, 5(4), 431-449.

Liu, T. (2019). Research on the influence of economic policy uncertainty on stock market heterogeneity based on investor perspective. Journal of Accounting, Business and Finance Research, 7(2), 51-58. https://doi.org/10.20448/2002.72.51.58

Machdar, N. (2019). Does CEO turnover affect stock market performance through company performance in Indonesian companies?. International Journal of Applied Economics, Finance and Accounting, 4(1), 15-21. https://doi.org/10.33094/8.2017.2019.41.15.21

Man, T. W., Lau, T., \& Chan, K. F. (2002). The competitiveness of small and medium enterprises: A conceptualization with focus on entrepreneurial competencies. Journal of Business Venturing, 17(2), 123-42.

McClelland, D. C. (1987). Human motivation. CUP Archive.

Moi, T., Adeline, Y. L., \& Dyana, M. L. (2011). Young adult responses to entrepreneurial intent. Researchers World, 2(3), 37.

Pavett, C. M., \& Lau, A. W. (1983). Managerial work: The influence of hierarchical level and functional specialty. Academy of Management Journal, 26(1), 170-7.

Smith, J. B., Mitchell, J. R., \& Mitchell, R. K. (2009). Entrepreneurial scripts and the new transaction commitment mindset: Extending the expert information processing theory approach to entrepreneurial cognition research. Entrepreneurship Theory and Practice, 33(4), 815-844.

Spencer, L. M., \& Spencer, P. S. (2008). Competence at Work models for superior performance. John Wiley \& Sons.

Stuart, T. E., Hoang, H., \& Hybels, R. C. (1999). Interorganizational endorsements and the performance of entrepreneurial ventures. Administrative Science Quarterly, 44(2), 315-49.

Zimmer, C. (1986). Entrepreneurship through social networks. The art and science of entrepreneurship. Ballinger, Cambridge, MA, 3:23. 